Research Article

Open Access

\title{
Towards to Changes in Blood Indices as Early Diagnosis of Retained Placenta
}

\author{
Ezzatollah Fathi and Hossein Hamali \\ Department of Clinical Sciences, Faculty of Veterinary Medicine, University of Tabriz, Tabriz, Iran
}

\section{Article Info}

\author{
*Corresponding author: \\ Ezzatollah Fathi \\ Department of Clinical Sciences \\ University of Tabriz \\ Tabriz, Iran \\ Tel: +98-41-36378743 \\ Fax: +98-41-36378734 \\ E-mail: ez.fathi@tabrizu.ac.ir \\ fathi_vet79@yahoo.com
}

Received: November 28, 2018

Accepted: December 21, 2018

Published: December 28, 2018

Citation: Fathi E, Hamali H. Towards to changes in blood indices as early diagnosis of retained placenta. Madridge J Immunol. 2018; 3(1): 65-68.

doi: $10.18689 / \mathrm{mjim}-1000115$

Copyright: (c) 2018 The Author(s). This work is licensed under a Creative Commons Attribution 4.0 International License, which permits unrestricted use, distribution, and reproduction in any medium, provided the original work is properly cited.

Published by Madridge Publishers

\begin{abstract}
Summary
This study aims to examine hematological parameters for early diagnosis of retained placenta (RP) during three stages of postpartum periods in dairy cattle. For this purpose, thirty post calving dairy cows with RP (group I) and healthy (group II) were selected ( $n=15$ each). The cows were placed into 3 stages of period, from 1 to 3 weeks after parturition. Then, blood samples were collected from two groups. No significant differences were observed in hematological indices between two groups of cattle. The results showed that RP does not cause to significant changes in some hematological parameters as well as total protein and albumin (Alb) when compared to the healthy cows $(p<0.05)$. Also, significant increases in the concentration of fibrinogen $(\mathrm{Fb})$ was observed in diseased cows during 1 to 2 weeks when compared to the healthy $(p<0.05)$. Our results indicated, in spite of hematological parameter, some serum indices including Fib could be successfully applied as indicators for RP in post calving dairy cattle. Therefore, blood indices cannot be used for early diagnosis of RP in dairy cattle.
\end{abstract}

Keywords: Hematological; Retained placenta; Post calving; Early diagnosis.

\section{Introduction}

Retained placenta (RP) results in following to some diseases including delayed gestation, infections, early parturition, uterine atony and abortion [1]. Moreover, it is well known that deficiencies of some minerals induce animals to $\operatorname{RP}[2,3]$. Investigation of hematological parameters are less-reported in dairy cattle. So this study aimed to measure, by a matched case-control study among post-calving dairy cows, the concentrations of hematological parameters as well as some serum indices as indicators for early diagnosis of RP in dairy cattle, probably to make any decision in treatment and decreasing the economic costs in dairy industry.

\section{Materials and Methods}

All Holstein cattle from two dairy farms located in Tabriz suburb were divided in two groups of RP (group I) and healthy (group II) ( $n=15$ each).

Cattle were excluded from the study if there was any clinical evidence of concurrent diseases. Blood samples were collected in duplicate from the jugular vein of both studied groups at weeks 1,2 and 3 after calving, with and without ethylene diaminetetraacetic acid (EDTA). Blood samples containing EDTA were used for evaluating plasma fibrinogen ( $\mathrm{Fb}$ ) level and complete blood count $(\mathrm{CBC})$. The data related to hematological indices of $C B C$, i.e., packed cell volume (PCV), hemoglobin $(\mathrm{Hgb})$, number of white blood cells (WBCs), differential cells count of neutrophils (Neu), B and, lymphocytes (Lym), monocytes (Mono) and red blood cells (RBCs), 
platelets (PLT) were determined by coulter count (vet Hemascreen 18, Hospitex Diagnostics, Italy). Fb was determined quantitatively by heat precipitation method at the day of sampling on centrifuged EDTA plasma. Total protein and Alb concentrations were determined using an automated analyzer (Eppendorf EPOS Analyzer 5060, Germany) with standard biuret and bromocresol green method, respectively.

Statistical analysis was performed using SPSS software (Ver. 16, IBM Corporation, and USA). The results were expressed as mean \pm SE at significance level of $p<0.05$.

\section{Results}

Statistical evaluations elucidated that there are no significant differences in total protein and Alb as well as hematologic indices of PCV, Hgb, RBCs, and PLT between diseased (group I) and healthy cows (Group II) (Table 1) $(p>0.05)$.

There were significant differences in $\mathrm{Fb}$ concentration and number of WBCs, Band and Neu in diseased cows when compared with clinically healthy cows (Figures 1A-1D) $(p<0.05)$. The concentration of serum Fb and Alb as well as other hematologic indices between the two groups are presented in table 1.
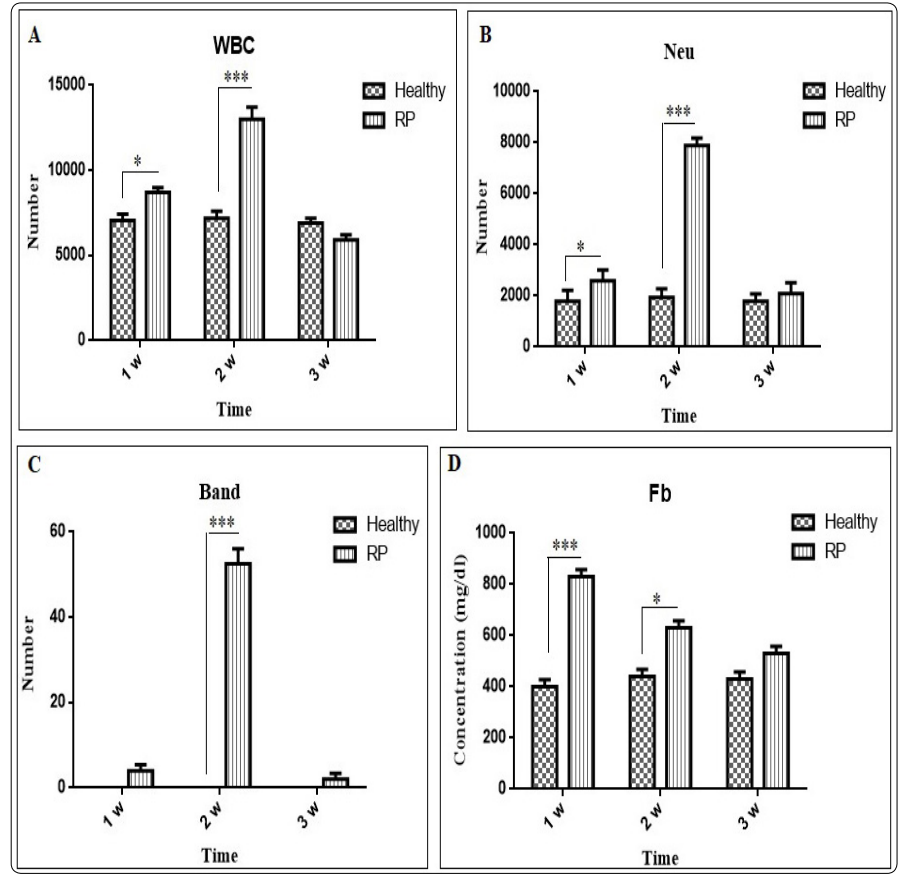

Figure 1. Hematological profiles and Fb concentration (mean $\pm \mathrm{SE}$ ) in cows with RP and clinically healthy at 1-3 weeks in post-calving. WBC: White blood cell; Neu: Neutrophil; Fb: Fibrinogen.

*Statistically significant $(P<0.05)$

*** Statistically significant $(P<0.001)$

Table 1. Hematological parameters of dairy cattle with RP and clinically healthy cows at 1-3 weeks in post-calving.

\begin{tabular}{|c|c|c|c|c|c|c|c|}
\hline \multirow{4}{*}{ Parameters } & \multicolumn{6}{|c|}{ Groups } & \multirow{4}{*}{$P$ value } \\
\hline & \multicolumn{3}{|c|}{$\mathrm{RP}$} & \multicolumn{3}{|c|}{ Healthy } & \\
\hline & \multicolumn{6}{|c|}{ Time } & \\
\hline & $1 \mathrm{w}$ & $2 w$ & $3 w$ & $1 \mathrm{w}$ & $2 w$ & $3 w$ & \\
\hline PCV (\%) & $36.10 \pm 0.15$ & $38.19 \pm 0.45$ & $37.33 \pm 0.36$ & $36.19 \pm 0.11$ & $35.47 \pm 0.35$ & $35.10 \pm 0.25$ & $>0.05$ \\
\hline $\mathrm{Hb}(\mathrm{g} / \mathrm{dl})$ & $11.51 \pm 0.23$ & $12.36 \pm 0.34$ & $12.60 \pm 0.15$ & $11.10 \pm 0.12$ & $12.30 \pm 0.35$ & $12.24 \pm 0.21$ & $>0.05$ \\
\hline $\operatorname{RBC}\left(\times 10^{6} \mu / \mathrm{l}\right)$ & $5.30 \pm 0.22$ & $6.15 \pm 0.32$ & $6.125 \pm 0.45$ & $5.15 \pm 0.32$ & $6.78 \pm 0.58$ & $6.10 \pm 0.13$ & $>0.05$ \\
\hline$W B C^{*} / \mu l$ & $8500 \pm 412.01$ & $13500 \pm 212.11$ & $6130 \pm 112.09$ & $7320 \pm 352.41$ & $7470 \pm 376.21$ & $7100 \pm 111.01$ & $<0.05$ \\
\hline $\mathrm{Neu} / \mu \mathrm{l}$ & $2890 \pm 0.31$ & $8100 \pm 0.55$ & $2400 \pm 0.22$ & $2090 \pm 0.56$ & $2180 \pm 0.50$ & $2000 \pm 0.56$ & $<0.05$ \\
\hline Band $^{*} / \mu \mathrm{l}$ & $3 \pm 0.03$ & $128 \pm 0.12$ & $1 \pm 0.19$ & $00.00 \pm 0.9$ & $00.00 \pm 0.0$ & $00.00 \pm 0.0$ & $<0.05$ \\
\hline 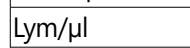 & $5100 \pm 0.12$ & $2980 \pm 0.37$ & $3460 \pm 0.11$ & $4700 \pm 0.21$ & $4650 \pm 0.22$ & $4050 \pm 0.29$ & $>0.05$ \\
\hline 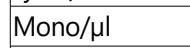 & $390 \pm 0.33$ & $1970 \pm 0.51$ & $65 \pm 0.13$ & $350 \pm 0.11$ & $332 \pm 0.31$ & $222 \pm 0.10$ & $>0.05$ \\
\hline Plt $\times 10^{6} / \mu \mathrm{l}$ & $390 \pm 31.02$ & $330.30 \pm 34.62$ & $320.90 \pm 41.11$ & $395.11 \pm 20.45$ & $390.51 \pm 30.51$ & $393.31 \pm 24.21$ & $>0.05$ \\
\hline Tp g/dl & $7.5 \pm 2.2$ & $7.2 \pm 1.2$ & $7.1 \pm 0.8$ & $6.9 \pm 0.3$ & $7.1 \pm 1.1$ & $7.0 \pm 0.4$ & 0.945 \\
\hline Alb g/dl & $3.3 \pm 0.4$ & $3.2 \pm 0.3$ & $3.2 \pm 0.4$ & $3.4 \pm 0.2$ & $3.4 \pm 0.6$ & $3.2 \pm 0.7$ & 0.419 \\
\hline $\mathrm{Fb}^{*} \mathrm{mg} / \mathrm{dl}$ & $850 \pm 1.1$ & $650 \pm 0.9$ & $550 \pm 0.7$ & $420 \pm 0.6$ & $460 \pm 0.4$ & $450 \pm 0.6$ & $<0.05$ \\
\hline
\end{tabular}

Data are presented as (Mean $\pm \mathrm{SE}$ )

RP retain placenta, PCV packed cell volume, $\mathrm{Hb}$ hemoglobin, $\mathrm{RBC}$ red blood cell, WBC white blood cell, Plt platelet, Tp total protein, Alb albumin, Fb fibrinogen, Neu neutrophil, Lym lymphocyte, Mono monocyte

*Statistically significant

\section{Discussion}

The costs imposed by RP can be considerable due to treatment costs, reduction in live weight gain, and reduced productive life span. In individual animals, blood sampling for evaluating e.g. the total leukocyte count may be helpful to indicate infectious disease. However, using total leukocyte count to detect infection is not informative enough in cattle like many other species. The importance of some hematological indices in three stages of postpartum periods is less documented in large animal veterinary medicine (dairy cattle). This research was performed in fifteen post-calving dairy cows complicated with the diseases of RP (group I). Also, fifteen clinically healthy cows were selected as control (group II). The cows in two groups from each farm were selected as pairs in the same sex and age. After physical examination, clinical findings were recorded for each case. Healthy cows were excluded from the study if there was any clinical evidence of concurrent diseases. Healthy cows and their results were taken as control values. In this research, it was tried to eliminate the effects of biasing factors by choosing calves as pairs similar in gender, and lack of statistical difference in age of each group $(p>0.05)$ helped us in establishing a statistically valid inference. The cows were placed into 3 stages of period, from 1 to 3 
weeks after parturition. Blood samples were collected from the jugular vein of two groups at weeks 1, 2 and 3 postpartum to determine hematological indices of PCV, $\mathrm{Hb}, \mathrm{WBCs}$, Neu, Band, Lym, RBCs, and PLT. Recently, some other parameters like APPs have been used following calving as an indicator of pending clinical metritis, ketosis and RP [1, 4-9]. The stages of diseases can be better evaluated by monitoring more than one analytic. Dairy cattle often develop pathologic conditions in the peripartum period and many parameters may be useful in their diagnosis. Total disease incidence in the several weeks after parturition accounts for a substantial proportion of all morbidity on many dairies with particularly high rates of mastitis, metritis, milk fever, displaced abomasum (DA), RP, ketosis, and fatty liver, among other problems [5,10-12]. The mentioned indices in this study should be used with caution in the week after calving because it could be difficult to distinguish between the physiologic status of calving and a pathologic inflammatory process. Determination of these parameters may also be use to manage the necessary treatment of diseased cows. There is a significant relation between metabolic and puerperal disorders and nutrition deficiencies after parturition in cows $[1,13]$. In individual animals, blood sampling for evaluating e.g. the total leukocyte count may be helpful to indicate infectious disease. However, using total leukocyte count to detect infection is not informative enough in cattle like many other species [14]. In this study, increase in the number of leukocytes as well as $\mathrm{Fb}$ during1 to 2 weeks in cattle with RP in comparison with clinically healthy cows may be due to the inflammatory nature of the disease (Figures 1A and 1D).

$\mathrm{Fb}$ is involved in blood coagulation as a precursor to fibrin, binds to red cells, and reduces their surface charge leading to cell aggregation. It is also involved in tissue repair, providing a matrix for migration of inflammatory cells, fibroblasts, and endothelial cells $[15,16]$. Fb has been used for many years as an indicator for inflammatory diseases such as RP as well as other inflammatory diseases in cattle $[15,17]$. Plasma Fb concentrations can remain unchanged or even decrease during an inflammatory condition. In our study, a significant increases in $\mathrm{Fb}$ was observed in $\mathrm{RP}$ diseased cows at 1 to 2 weeks $(p<0.05)$ compared to the healthy cows (Figure 1D). This may reflect consumption of the protein at the inflamed area (Uterine) in diseased cows which transiently can exceed the production. Measurement of $\mathrm{Fb}$ in cattle can be use to discriminate between acute and chronic inflammation, so the stage of disease can be evaluated better by monitoring more than one parameter. Increase in the $\mathrm{Fb}$ has been reported in other inflammatory diseases in cattle $[18,19]$.

Many viruses as well as bacterial uterine pathogens are commensal in clinically healthy calves. However, during coinfection, they can cause serious uterine diseases in cattle. In our study, reduction in the number of leukocytes at 3 week in RP group in comparison with clinically healthy cows may be due to consumption of $\mathrm{Neu}$ and the effects of various pathogens present in the area (uterine) (Figure 1B). The higher level of Band Neu during 2 week in RP group is due to regenerative response of bone marrow to consumption of Neu at the inflamed area (Figure 1C).

In this study, no substantial changes were seen among other hematological parameters between the RP and control groups in all three stages after calving $(p>0.05)$. Despite the increment in total protein and decrease in albumin concentration in diseased cows, the difference between the two groups was not statistically significant $(p>0.05)$. Therefore, it may be considered that this issue may be influential in retained fetal membrane. In one research, it was determined that the hematological indices as well as other serum biochemical parameters concentration did not differ in the RP group [1]. Ocal et al. and Akar et al. reported that cows $<3$ years old with RP had higher serum Ca levels (9.41 and $8.72 \mathrm{mg} / \mathrm{dl}$ ) than cows $>6$ years old $[1,20]$. Some other indices such as blood enzymes have been investigated in previous studies. For example, significant increases in the blood concentration of AST, GGT and $\mathrm{CK}$ have been reported in some metabolic diseases in cows after calving [13,21, 22]. Increased in the activities of these enzymes may have been associated with cholestasis, the disruption of normal hepatobiliary circulation, muscle disorders, hepatic lipidosis and/or increased mobilization of $\mathrm{Ca}$ from tissues to serum in response to hypocalcemia $[13,17,23]$.

\section{Conclusion}

This study shows that hematological indices should be used with caution in different stages after calving; however, the physiologic status of a cow can have an influence on these parameters. Briefly, except for Fb and WBC, Neu and Band counts, hematological parameters should not be used independently with other biochemical indices such as the quantity of the mineral substances as well as some serum enzymes in which case they could be successfully applied as indicators for early diagnosis and management of treatment in cows with RP.

\section{Acknowledgment}

This research was supported by a grant from the University of Tabriz.

\section{Conflict of Interest}

The authors declare no conflict of interest.

\section{References}

1. Akar Y. Concentrations of Some Minerals in Cows with Retained Placenta and Abortion. Turk J Vet Anim Sci. 2005; 29: 1157-1162.

2. Laven RA, Peters AR. Bovine retained placenta: etiology, pathogenesis and economic loss. Vet Rec. 1996; 139(19): 465-471.

3. Hurley WL, Doane RM. Recent developments in the roles of vitamins and minerals in reproduction. J Dairy Sci. 1989; 72: 784-804. doi: 10.3168/jds. S0022-0302(89)79170-0

4. Fathi E, Hamali $\mathrm{H}$, Tolouei Kaleibar M, Farahzadi R. Application of acute phase proteins as indicators of retained placenta and their relation to energy metabolites in postcalving dairy cows. Comp Clin Pathol. 2013 24: 47-51 
5. Huzzey JM, Duffield TF, LeBlanc SJ, et al. Short communication: haptoglobin as an early indicator of metritis. J Dairy Sci. 2009; 92(2): 621-625. doi: 10.3168/jds.2008-1526

6. Humblet MF, Guyot $H$, Boudry B, et al. Relationship between haptoglobin, serum amyloid $A$, and clinical status in a survey of dairy herds during a 6-month period. Vet Clin Pathol. 2006; 35: 188-193. doi: 10.1111/j.1939-165X.2006.tb00112.x

7. Khoshvaghti A, Nazifi S, Vafafar A, Gheisari HR. Evaluation of serum and milk haptoglobin in some inflammatory diseases of cattle. Int J Vet Res. 2009; 3(1): 31-36.

8. Nazifi S, Khoshvaghti A, Gheisari HR. Evaluation of serum and milk amyloid A in some inflammatory diseases of cattle. Iranian J Vet Res. 2008; 9(3): 222-226.

9. Akerstedt $M$, Persson WK, Sternesjö A. Haptoglobin and serum amyloid $A$ in relation to the somatic cell count in quarter, cow composite and bulk tank milk samples. J Dairy Res. 2007; 74: 198-203. doi: 10.1017/ S0022029906002305

10. Ingvartsen KL. Feeding- and management-related diseases in the transition cow: physiological adaptations around calving and strategies to reduce feeding-related diseases. Anim Feed Sci Technol. 2006; 126 (34): 175-213. doi: 10.1016/j.anifeedsci.2005.08.003

11. Ametaj BN, Bradford BJ, Bobe G, et al. Strong relationships between mediators of the acute phase response and fatty liver in dairy cows. Can J Anim Sci. 2005; 85(2): 165-175. Doi: 10.4141/A04-043

12. Goff JP. Major advances in our understanding of nutritional influences on bovine health. J Dairy Sci. 2006; 89(4): 1292-1301. doi: 10.3168/jds. S0022-0302(06)72197-X

13. Sahinduran S, Kenan S, Tulay B, Metin KA, Mehmet CK. Evaluation of Some Haematological and Biochemical Parameters Before and After Treatment in Cows with Ketosis and Comparison of Different Treatment Methods. J Anim Vet Adv. 2010; 9(2): 266-271. doi: 10.3923/javaa.2010.266.271
14. Taylor JA. Leukocyte responses in ruminants. In: Feldman BF, Zinkl JG, Jain NC (eds) Schalm's veterinary hematology. Lippincott Williams \& Wilkins, Philadelphia, 2000; 391-404.

15. Eckersall PD, Conner JG. Bovine and canine acute phase proteins. Vet Res Communi. 1988; 12(3): 169-178.

16. Thomas JS. Overview of plasma proteins. In: Feldman BF, ZinkI JG, Jain NC (eds) Schalm's veterinary hematology. Lippincott Williams \& Wilkins, Philadelphia, 2000; 891-898.

17. McSherry BJ, Horney FD, deGroot JJ. Plasma fibrinogen levels in normal and sick cows. Can J Com Med. 1970; 34: 191-197.

18. Cheryk LA, McGrevy KE, Gentry PA. Alterations in platelet function and acute phase proteins induced by Pasteurella haemolytica A1. Can J Vet Res. 1998; 62: 1-8.

19. Horadagoda A, Eckersall PD, Hodgson JC, Gibbs HA, Moon GM. Immediate responses in serum TNF- $\alpha$ and acute phase protein concentrations to infection with Pasteurella hemolytica A1 in calves. Res Vet Med. 1994; 57(1): 129-132.

20. Ocal $\mathrm{H}$, Torkoz $\mathrm{Y}$, Cetin $\mathrm{H}$, et al. Retensiyo sekundinarumlu ineklerde kan serumu kalsiyum (Ca) ve fosfor (P) d.zeyleri zerineal ÝBma. Turk J Vet Anim Sci. 1999; 23(3): 591-595.

21. Grummer RR. Etiology of lipid-related metabolic disorders in periparturient dairy cows. J Dairy Sci. 1993; 76: 3882-3896. doi: 10.3168/jds.S00220302(93)77729-2

22. Dann HM, Morin DE, Bollero GA, et al. Perpartum intake, postpartum induction of ketosis and preparturient disorders affect the metabolic status of dairy cows. J Dairy Sci. 2005; 88: 3249-3264. doi: 10.3168/jds. S0022-0302(05)73008-3

23. Karmer JW, Hoffmann WE. Clinical Enzymology. 5th edn. In: Kaneko JJ, Harvey JW, Bruss ML (eds) Clinical Biochemistry of Domestic Animals, Academic Press, Sandiago, 1997; 315-317. doi: 10.1023/A:1017137803035 